\title{
Ekranisasi dan Nilai Religius Novel Wedding Agreement Karya Mia Chuz
}

\author{
Noor Tsalis Yuni Kusumawati ${ }^{1)}$ \\ Universitas Indraprasta PGRI \\ Jalan Nangka No. 58 C/TB. Simatupang, Tanjung Barat, Jakarta Selatan 12530
}

\author{
Apsanti Djokosujanto ${ }^{2}$ \\ Universitas Indraprasta PGRI \\ Jalan Nangka No. 58 C/TB. Simatupang, Tanjung Barat, Jakarta Selatan 12530 \\ Bambang Sumadyo ${ }^{3)}$ \\ Universitas Indraprasta PGRI \\ Jalan Nangka No. 58 C/TB. Simatupang, Tanjung Barat, Jakarta Selatan 12530 \\ salsaetsalist@gmail.com ${ }^{1)}$
}

\begin{abstract}
The purpose of this research is to show the ecranization and religious values used in Mia Chuz's Wedding Agreement novel. This research is in the form of a qualitative descriptive with a content analysis method based on the objects obtained from the ecranization and religious values contained in the Wedding Agreement novel by Mia Chuz. The results of this study indicate that there are 118 ekranization processes that occur in the elements of the plot, character, and setting, namely the existence of shrinkage, addition, and variation change. The shrinking of the plot, characters, and settings occurs because the media used in making novels and films are different. The addition of the plot, characters, and settings in the film as a whole is still relevant to the story in the novel, it's just that the visualization in the film is made more interesting, while for the varied changes in plot, character, and setting made in the visualization to the form of the film as a whole it is not far from being depicted in the novel. The religious value in the novel Wedding Agreement by Mia Chuzfound 99 findings of religious values which include (a) the human relationship with God as many as 63 findings, (b) the human relationships with human is 17 finding, $(c)$ the human-to-self relationships is 16 findings and $(d)$ human relations with nature as many as 3 findings.
\end{abstract}

Keywords: Wedding Agreement Novel, Ekranization and Religious Value.

\begin{abstract}
Abstrak
Tujuan dari penelitian ini adalah untuk menunjukkan ekranisasi dan nilai religius yang terdapat pada novel Wedding Agreement karya Mia Chuz. Penelitian ini berbentuk deskriptif kualitatif dengan metode analisis isi (content analysis) berdasarkan objek yang diperoleh dari ekranisasi dan nilai religius yang terdapat pada novel Wedding Agreement karya Mia Chuz. Hasil penelitian ini menunjukkan bahwa terdapat 118 proses ekranisasi yang terjadi pada unsur alur, tokoh, dan latar, yaitu adanya penciutan, penambahan, dan perubahan variasi. Penciutan alur, tokoh, dan latar terjadi karena media yang digunakan dalam pembuatan novel dan film berbeda. Penambahan alur, tokoh, dan latar dalam film secara keseluruhan masih relevan dengan cerita yang ada dalam novel, hanya saja pada visualisasi dalam film dibuat lebih menarik, sedangkan untuk perubahan bervariasi alur, tokoh, dan latar yang dilakukan dalam visualisasinya ke bentuk film secara keseluruhan tidak jauh melenceng dari penggambaran yang ada dalam novel. Adapun nilai religius dalam novel Wedding Agreement karya Mia Chuz ditemukan sebanyak 99 temuan nilai religious yang meliputi (a)
\end{abstract}

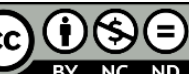

Creative Commons Attribution-NonCommercial-NoDerivatives 4.0 International License 
hubungan manusia dengan Tuhan sebanyak 63 temuan, (b) hubungan manusia dengan manusia sebanyak 17 temuan, (c) hubungan manusia dengan diri sendiri sebanyak 16 temuan dan (d) hubungan manusia dengan alam sebanyak 3 temuan.

Kata Kunci: Novel Wedding Agreement, Ekranisasi dan Nilai Religius.

\section{PENDAHULUAN}

Karya sastra adalah hasil karya manusia, baik lisan atau tulisan yang menggunakan bahasa sebagai media pengantar dan memiliki nilai estetik (keindahan bahasa) yang dominan. Di samping itu, karya sastra juga bersifat menghibur dan mendidik. Karya sastra juga cerminan budaya bangsa yang tidak bisa lepas dari jiwa dan masyarakat pengarangnya, serta tidak lepas pula dari pengaruh sosial budaya tempat karya itu diciptakan. Di Indonesia, karya sastra terbagi menjadi dua yaitu karya sastra lama dan karya sastra baru. Adapun bentuk karya sastra lama berupa puisi yang terikat seperti syair, pantun, hikayat, mite, dan dongeng. Sedangkan karya sastra baru berupa puisi bebas dan kontemporer seperti cerpen, novel, dan drama. Jadi, dengan adanya perkembangan karya sastra penulis ataupun sastrawan kini bebas menuangkan gagasan ataupun imajinasi menjadi suatu karya seperti halnya novel.

Novel merupakan pengungkapan dari fragmen kehidupan manusia dalam jangka yang lebih panjang. Itu artinya peristiwa yang ada lebih kompleks atau beragam (Ginanjar, 2012: 5). Pendapat lain juga disampaikan bahwa novel untuk seorang pengarang adalah wujud dari ide, pikiran, perasaan, ilmu, semangat, dan keyakinan yang dituangkan dalam cerita. Oleh sebab itu, novel dapat menjadi inspirasi bagi pembacanya (Anto dan Rahman, 2018: 23; Rahman, dkk. 2018: 13). Keunggulan novel dalam mengungkapkan cerita secara lebih jelas membuat novel mendapat apresiasi yang besar dari pembaca. Tema-tema yang diangkat dalam novel pun beragam, misalnya tentang pendidikan dalam novel Laskar Pelangi karya Andrea Hirata, persahabatan dan cinta dalam novel Perahu Kertas karya Dewi Lestari dan masih banyak tema-tema lainnya.

Seiring dengan perkembangan zaman, khalayak umum tidak hanya mengenal karya sastra melalui media cetak, tetapi juga melalui media audio visual seperti film, sinetron, video klip, film dokumenter, web series dan sebagainya. Media audio visual menawarkan hiburan yang menarik, lebih canggih, dan mudah bagi para penikmat karya sastra, contohnya film, dengan menonton film kita hanya menggunakan dua panca indra kita yaitu mata dan telinga. Lain halnya apabila harus membaca novel, banyak waktu yang harus dikeluarkan dibandingkan menonton film. Hal tersebut menyebabkan media audio visual lebih digandrungi daripada media cetak. Media audio visual dirasa lebih menarik, khususnya bagi orang-orang yang tidak suka membaca.

Perkembangan karya sastra pada zaman sekarang semakin maju dengan adanya film yang diadaptasi dari karya sastra, khususnya novel seperti Habibi dan Ainun, Filosofi Kopi, dan sebagainya. Pengadaptasian dari novel menjadi film dilatarbelakangi oleh masyarakat yang menyambut hangat adanya suatu novel hingga menjadi bestseller dan dicintai oleh banyak kalangan. Berawal dari hal tersebut, maka banyak produser film yang tertarik untuk mengadaptasi cerita dalam 
novel ke layar lebar dengan harapan film tersebut akan sukses. Tahun 1951 telah dilakukan proses adaptasi dari novel ke bentuk film yaitu ketika sutradara Huyung memfilmkan drama yang berjudul Antara Bumi dan Langit karya Armijn Pane.

Proses pengadaptasian atau pelayarputihan dari karya sastra khususnya novel ke film disebut proses ekranisasi (Eneste dalam Rokhmansyah, 2014: 178). fenomena tersebut marak dilakukan oleh para insan perfilman. Fenomena ini menjadi isu mutakhir dalam beberapa tahun terakhir ini. Menurut Saryono (2015) fenomena ekranisasi merupakan sebuah Hybrid Literary Multimedia, fenomena tersebut muncul untuk mengejar pasar. Sejalan dengan pendapat tersebut, Damono (2005: 98) menyatakan bahwa dalam beberapa dasawarsa terakhir ini semakin banyak novel yang biasanya dikategorikan sebagai sastra populer, diangkat ke layar perak setelah sebelumnya diubah bentuknya menjadi skenario film. Pemindahan dari novel ke layar putih mau tidak mau mengakibatkan timbulnya berbagai perubahan. Suseno (2010) mengatakan bahwa dalam proses ekranisasi bisa terjadi penciutan, penambahan (perluasan), dan perubahan dengan sejumlah variasi.

Menurut Pujiati (dalam Melinda, 2013: 2) menyebutkan bahwa transformasi dari dua dunia yang berbeda (antara bahasa dan audio visual) membawa perubahan mengiringi konsep ekranisasi sebagai proses perubahan. Perubahan dalam proses alih wahana ini tentu akan ada perbedaan dari segi tokoh, alur, setting, dan lainlain.

Dalam melakukan perubahan terhadap novel yang diadaptasi menjadi film tentu membuktikan proses kreatif. Proses kreatif dalam pengangkatan novel ke layar lebar dapat berupa penambahan maupun pengurangan jalannya cerita. Hal tersebut terkait dengan faktor narasi tetapi tidak mengesampingkan faktor estetik. Proses kreatif tersebut yang diterapkan sutradara Archie Hekagery dalam pengangkatan novel ke layar lebar yang berjudul Wedding Agreement. Proses adaptasi dari karya Mia Chuz ke bentuk film garapan sutradara Archie Hekager inilah yang akan menjadi objek kajian dalam penelitian ini.

Wedding Agreement merupakan cerita karya Mia Chuz yang ditulis di situs Wattpad pada tahun 2018. Wedding Agreement pernah menempati peringkat kesatu Genre romance di Wattpad pada 27 Juli 2018 dan telah dibaca lebih dari 6 juta kali. Setelah menarik minat pembaca di situs Wattpad, pada tanggal 27 Juli 2019 Wedding Agreement diterbitkan oleh Laiqa dan sudah dicetak ulang beberapa kali. Wedding Agreement merupakan sebuah film drama Indonesia yang tayang pada 8 agustus 2019 produksi Starvision Plus.

Wedding Agreement mengisahkan tentang Bian yang rela dijodohkan dengan Tari demi membahagiakan ibunya, meskipun ia sudah menjalin hubungan selama lima tahun dengan kekasihnya, Sarah. Kekuatan tekad Tari untuk mempertahankan perkawinan ini sekaligus merebut hati Bian dari Sarah. Film Wedding Agreement juga mengusung tema sebuah pengorbanan seorang istri kepada suami dengan segala rintangan yang dihadapi. Selain itu ada nilai religius yang ingin disampaikan dalam film tersebut yang mana nilai religius itu mengajak seseorang untuk berbuat kebaikan sesuai dengan ajaran agama.

Nilai religius merupakan pondasi yang penting dalam tatanan kehidupan. Nilai religius adalah dasar dari terbentuknya sebuah budaya religius, karena jika setiap orang tidak memiliki suatu kereligiusan dalam hidupnya maka mustahil dapat

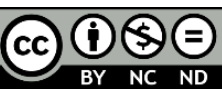

Creative Commons Attribution-NonCommercial-NoDerivatives 4.0 International License 
terbentuk suatu budaya religious (Fathurrohman, 2015: 52). Adapun aspek-aspek nilai religius terdiri dari (a) hubungan manusia dengan Allah, (b) hubungan manusia dengan diri sendiri, (c) hubungan manusia dengan manusia lain, (d) hubungan manusia dengan lingkungan alam Ali (2013: 368)

Setelah peneliti membaca berulang-ulang novel Wedding Agreement karya Mia Chuz, ditemukan beberapa nilai religius yang terdapat di dalamnya. Nilai-nilai religius ini memiliki pengaruh yang sangat signifikan bagi kedua pemeran toko utama dalam novel tersebut. Berdasarkan uraian di atas, peneliti tertarik untuk menungkap dan menunjukkan ekranisasi dan nilai religius pada novel Wedding Agreement karya Mia Chuz dan film dengan judul yang sama karya Archie Hekagery.

\section{METODE}

Penelitian ini berbentuk deskriptif kualitatif dengan metode analisis isi (content analysis). Penelitian ini bersifat atau memiliki karakteristik bahwa datanya dinyatakan dalam keadaan apa adanya (natural setting) dengan tidak diubah dalam bentuk simbol atau bilangan (Kasiram, 2010: 76). Pengambilan sampel penelitian ini menggunakan purposive sampling atau subfokus yang ditentukan sesuai judul penelitian (Riduwan, 2010: 63). Data dalam penelitian ini diperoleh melalui membaca, menganalisis, menonton, dan mendeskripsikan kemudian menghitung jumlah proses ekranisasi dari novel menjadi film dan nilai religius pada novel Wedding Agreement karya Mia Chuz dalam bentuk persentase dengan rumus sebagai berikut.

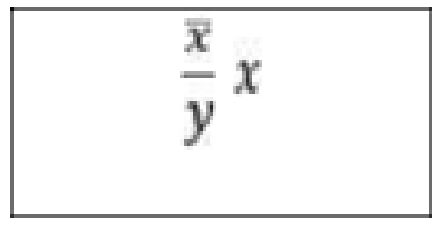

Keterangan:

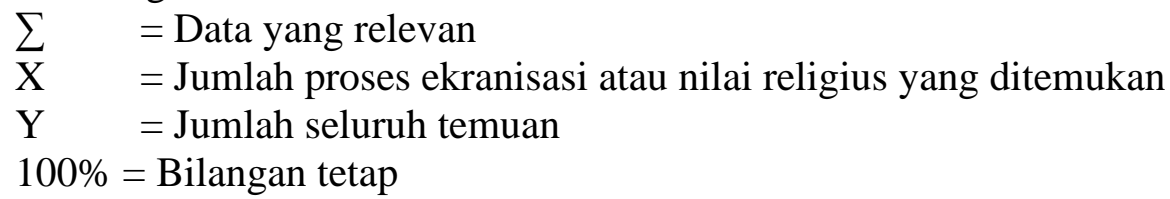

\section{HASIL DAN PEMBAHASAN}

\section{Hasil}

Di dalam penelitian ini, setiap peristiwa dalam novel maupun film akan dijabarkan menjadi episode cerita. Novel Wedding Agreement karya Mia Chuz yang terdiri atas 28 subbab ini setelah dilakukan pengklasifikasian menjadi 113 bagian cerita. Film Wedding Agreement karya Archie Hekagery yang memiliki judul yang sama dengan novel aslinya ini terdiri dari 85 Scene. Sesuai dengan tujuan yang telah 
ditetapkan maka penelitian ini memperoleh hasil berupa proses ekranisasi alur, tokoh, dan latar dalam novel dan film Wedding Agreement dilihat dari kategorisasi aspek penciutan, penambahan, dan perubahan bervariasi serta nilai religious di dalamnya. Hasil dari penelitian ini disajikan dalam persentase tabel sebagai berikut:

Tabel 1. Persentase Proses Ekranisasi Novel Wedding Agreement Karya Mia Chuz Berdasarkan Aspek Penciutan, Penambahan, dan Perubahan

\section{Bervariasi}

\begin{tabular}{lllc}
\hline \multicolumn{1}{c}{ Ekranisasi } & Alur & Latar & Tokoh \\
\hline Penciutan & 60 & 9 & 6 \\
Penambahan & 14 & 4 & 4 \\
Perubahan Variasi & 14 & 4 & 4 \\
Jumlah Per Aspek & 88 & 17 & 13 \\
Total Temuan & & 118 & \\
Persentase & $75 \%$ & $14 \%$ & $11 \%$ \\
Jumlah Persentase & & $100 \%$ &
\end{tabular}

Tabel 2. Persentase Nilai Religius pada Novel Wedding Agreement Karya Mia Chuz

\begin{tabular}{llcc}
\hline \multicolumn{1}{c}{ Aspek Religius } & \multicolumn{1}{c}{ Penyajian Data } & Total Temuan & Persentase \\
\hline Hubungan manusia & Membaca Al-qur'an & 5 & $5,05 \%$ \\
dengan Tuhan & Menutup aurat & 4 & $4,04 \%$ \\
& Dzikir & 1 & $1,01 \%$ \\
& Berdoa & 21 & $21,21 \%$ \\
& Bersyukur & 13 & $13,13 \%$ \\
Hubungan manusia & Salat & 19 & $19,20 \%$ \\
dengan manusia & Peakraban & 4 & $4,04 \%$ \\
& Berdakwaraan & 5 & $5,05 \%$ \\
Hubungan manusia & Tolong-menolong & 4 & $4,04 \%$ \\
dengan dirinya sendiri & Muharasabah & 5 & $4,04 \%$ \\
& Pantang menyerah & 3 & $5,05 \%$ \\
& Mandiri & 3 & $3,03 \%$ \\
Hubungan manusia & Bijak & 4 & $3,03 \%$ \\
dengan alam sekitar & dan keagungan ciptaan & 3 & $4,04 \%$ \\
& Tuhan & & $1,01 \%$ \\
\hline
\end{tabular}

Total

99

$100 \%$

\section{Pembahasan}

Deskripsi informasi tentang penelitian ini adalah film Wedding Agreement karya Archie Hekagery yang diadaptasi dari novel berjudul Wedding Agreement karya Mia Chuz yang diterbitkan pada tahun 2019 oleh Laiqa dengan tebal 328 
halaman. Film tersebut menghadirkan film bergenre drama romantis yang mengandung nilai-nilai religius. Film ini dirilis pada tanggal 8 Agustus 2019 dan berdurasi 1 jam 40 menit. Film ini sukses memperoleh perhatian dari masyarakat yang memiliki potensi membuat para penontonnya tersenyum, merasa gemas dan kesal serta tersentuh hatinya di beberapa adegan tersebut.

Novel ini berkisah tentang sepasang suami-istri. Btari Hapsari dan Byantara Wicaksana. Tari adalah pengusaha muda yang sukses dengan usaha roti goreng dan sering menghadiri seminar tentang wirausahanya, sedangkan Bian bekerja sebagai insinyur. Mereka menikah bukan saling mencintai, tetapi perjodohan orang tua mereka. Setelah akad nikah, Bian memberikan Tari selembar kertas perjanjian yang bermaterai, bahwa mereka tidak boleh mengurusi kehidupan satu sama lain, dan pada saat usia pernikahan mereka berusia satu tahun, mereka akan bercerai. Bian tidak mencintai Tari karena sebelumnya dia sudah bertunangan dengan Sarah. Tari mencoba bersabar. Setiap hari Tari bersikap seperti suami-istri pada umumnya, Tari rajin menyiapkan keperluan Bian dan membuatkan makanan Soto Betawi walaupun Bian tidak pernah mau memakannya. Di sisi lain Bian masih bertemu dengan Sarah dan berjanji akan menikahi Sarah setelah dirinya bercerai dari Tari. Bian dan Tari bersandiwara sebagaimana pasangan suami-istri di beberapa momen, seperti pada acara ulang tahun Ayah Bian dan pada saat Bude dan Pakde Tari datang ke rumah. Suatu saat, Bian jatuh sakit, walaupun dengan sikapnya yang datar dan dingin kepada Tari, Tari tetap sabar mengurusi Bian, perlahan watak Bian mulai melunak, bahkan mengizinkan Tari menyuapinya bubur. Hal ini membuat Tari menjadi bahagia. Bian dan Tari semakin dekat karena sikap Tari yang baik dan sabar. Bian merasa Tari bisa membuatnya berubah ke arah yang lebih baik. Pada suatu hari Bian menerima telpon bahwa Sarah kecelakaan dan dirawat di rumah sakit. Tari menemani Bian ke rumah sakit dan menunggu di luar. Tari merasa sedih dan kecewa ketika melihat Bian dan Sarah berpelukan. Kemudian Tari memutuskan pergi untuk sementara waktu dan menenangkan diri. Beberapa kali Bian menghubungi Tari tapi diacuhkan. Singkat cerita Sarah menemui Bian di rumahnya yang sedang menunggu Tari pulang. Akhirnya Sarah memutuskan untuk menerima keadaan bahwa hubungannya dengan Bian tidak dilanjutkan, Sarah bercerita bahwa selama ia terpuruk Aldi selalu menemaninya dan akan menikah dengan Aldi. Tari introspeksi diri dan akhirnya Tari sadar bahwa tempat istri adalah berada di sisi suaminya dalam keadaan apa pun. Akhirnya Tari pulang dan mereka hidup bahagia selamanya.

Dari pemaparan tabel hasil penelitian dapat dijelaskan bahwa proses ekranisasi alur, tokoh dan latar dalam novel Wedding Agreement berdasarkan penciutan, penambahan, dan perubahan bervariasi berjumlah 118 bagian atau scene cerita. Dengan ketentuan perubahan pada alur ditemukan 88 perubahan dengan persentase $75 \%$, yaitu penciutan pada alur sebanyak 60 bagian cerita, contoh kutipannya: "Bian menatap Tari yang tengah tidur di sampingnya untuk pertama kali. Cerita tersebut merupakan bagian yang dihilangkan. Penambahan pada alur sebanyak 14 scene, dengan contoh kutipan: "Tari menyiapkan sarapan untuk Bian tetapi Bian menolak untuk memakannya". Pada perubahan bervariasi pada alur sebanyak 14 bagian cerita, seperti dalam kutipan novel Tari tertidur di sofa saat 
menunggu Bian pulang dari kantor. sedangkan dalam filmnya Tari membaca Alquran sembari menunggu Bian pulang dari kantor.

Perubahan pada tokoh ditemukan 17 perubahan dengan persentase $14 \%$, yaitu penciutan pada tokoh sebanyak 6 tokoh, tokoh Dian dalam novel sebagai adik Sarah saat kecelakaan dihilangkan. Penambahan pada tokoh sebanyak 4 tokoh, seperti munculnya paman Bian dalam film saat ulang tahun Papa Bian. Sedangkan bagian penambahan variasi pada tokoh sebanyak 3 tokoh, seperti penggambaran tokoh Ami dalam novel adalah sosok yang bijaksana, dewasa, dan feminim, tetapi dalam film, Ami justru digambarkan menjadi sosok yang tomboi, ramai, dan humoris.

Adapun perubahan pada latar ditemukan 13 perubahan dengan persentase $11 \%$ yaitu penciutan pada latar terdapat 9 latar, contoh pada kutipan novel Bian dan Tari bertemu di restoran cepat saji untuk mengenal lebih jauh sebelum memutuskan melanjutkan perjodohan. Pada bagian ini dihilangkan dalam cerita filmnya. Sedangkan penambahan pada latar sebanyak 4 latar seperti dalam Film diceritakan Bian dan Tari jalan-jalan di sekitar Sudirman. Kemudian bagian penambahan bervariasi terjadi sebanyak 4 latar, seperti dalam cerita novel bahwa Ayah Bian merayakan ulang tahun di Hotel Bintang Lima sedangkan dalam film Ayah Bian merayakan ulang tahun di sebuah taman.

Sementara deskripsi temuan penelitian nilai religius dalam novel Wedding Agreement ditemukan sebanyak 99 temuan. Dengan ketentuan hubungan manusia dengan Tuhan sebanyak 63 temuan dengan persentase 64\%. Hubungan manusia dengan Tuhan dapat dirinci dengan sifat-sifat sebagai berikut, (1) membaca Alquran sebanyak 5 temuan, contoh pada kutipan novel: "Ia terbiasa menyetel alarm pukul setengah empat pagi, jadi masih ada waktu untuk salat Tahajud dan membaca Alquran hingga waktu Subuh." (Chuz, 2019: 70). Dari kutipan tersebut terlihat bahwa Tari membaca Alquran saat dini hari, ia membaca ayat-ayat Alquran untuk mencari petunjuk atas permasalahannya. Alquran juga berfungsi sebagai obat penyembuh. (2) menutup aurat sebanyak 4 temuan, contoh kutipan novelnya: "Bian menatap istrinya. Tari selalu menggunakan kerudung saat di rumah. Belum pernah sekali pun ia melihat Tari tanpa kerudung. Istrinya juga selalu memakai pakaian tertutup, seperti saat ini." (Chuz, 2019: 33). Kutipan tersebut menjelaskan bahwa Tari menutup auratnya walaupun di hadapan suaminya meskipun di dalam rumah. Karena menutup aurat bagian dari perintah agama. (3) dzikir sebanyak 1 temuan, contoh kutipan novelnya: Tari mengucapkan istighfar berkali-kali. "Ya Allah, ampuni kesalahan hamba," doanya dalam hati. (Chuz, 2019: 107). Beristighfar merupakan bagian dari dzikir, dengan tujuan senantiasa mengingat Allah. (4) berdoa sebanyak 21 temuan, contoh kutipan novelnya: "Bismillah. Bila ini sudah menjadi takdir-Nya, ia akan menjalaninya sepenuh hati." (Chuz, 2019: 7). Berdoa bagian dari perbuatan yang bertujuan untuk meminta dan memohon yang terbaik dari Allah. Sebagaimana yang dilakukan pada tokoh Tari saat menerima perjodohan dari kedua orang tuanya. (5) bersyukur sebanyak 13 temuan, contoh kutipan novelnya: "Ia bersyukur memiliki sahabat yang selalu mendukungnya dalam situasi apa pun." (Chuz, 2019: 16). Dalam kutipan ini seorang tokoh sedang bersyukur. Bersyukur merupakan ungkapan terima kasih atas apa yang didapat dalam hidupnya. dan (6) salat sebanyak 19 temuan, contoh kutipan novelnya: "Iya,

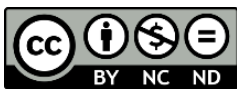

Creative Commons Attribution-NonCommercial-NoDerivatives 4.0 International License 
Pakde. Tadi malam kan sudah janji mau berangkat bareng untuk subuhan di masjid." (Chuz, 2019: 68). Salat subuh yang merupakan bagian dari salat wajib lima waktu tetap dilakukan oleh tokoh, Pakde dengan berjamaah di masjid walaupun sedang menginap di rumah keponakannya.

Aspek hubungan manusia dengan manusia dalam novel Wedding Agreement karya Mia Chuz ditemukan sebanyak 17 temuan dengan persentase $17 \%$. Hubungan manusia dengan manusia dapat dirinci sebagai berikut, (1) keakraban sebanyak 4 temuan, contoh kutipan novelnya: Ia memeluk erat sahabatnya. "Makasih udah datang." Tari balas memeluk. Ia sempat curhat dengan Ami tentang Bian. (Chuz, 2019: 16). Dalam kutipan tersebut terlihat sikap Tari yang memeluk erat sahabatnya. Tari sangat berterima kasih karena datang ke acara pernikahannya. Keakraban dapat melekatkan persaudaraan antar manusia, saling bercengkerama membantu sesama. (2) persaudaraan sebanyak 5 temuan, contoh kutipan novelnya: Mama mengembalikan kotak itu ke pangkuan Tari. "Kalau menolak pemberian Mama, berarti kamu nggak sayang sama Mama." (Chuz, 2019: 113). Dari kutipan tersebut terlihat bahwa Mama Bian sangat menyayangi Tari. Dia memberikan kotak perhiasan mahal pada Tari sebagai bukti kasih sayangnya, tetapi Tari merasa tidak pantas menerimanya. Rasa persaudaraan sangat penting untuk terus dipupuk supaya kehidupan menjadi indah dan damai. (3) berdakwah sebanyak 4 temuan, contoh kutipan novelnya: Ia mungkin tidak bisa membuat hati suaminya berubah, tetapi siapa tahu tausiah dari ustaz bisa membuat hati dan pikiran Bian sedikit terbuka. (Chuz, 2019: 144). Berdakwah merupakan salah satu cara untuk menyebarkan kebaikan dan bermanfaat bagi orang banyak. Kutipan tersebut terlihat Tari yang mengajak Bian menghadiri pengajian di masjid dekat rumahnya dan berharap Bian terbuka hati dan pikirannya. (4) tolongmenolong sebanyak 4 temuan, contoh kutipan novelnya: Tari membantu budenya memasukkan es batu ke mangkuk berisi sup buah. (Chuz, 2019: 7). Kutipan tersebut terlihat Tari yang membantu Budenya menyiapkan hidangan untuk keluarga Bian yang sedang bertamu ke rumah untuk melamar Tari. Sikap tolong-menolong merupakan perbuatan baik yang dapat meringankan beban manusia.

Adapun aspek hubungan manusia dengan diri sendiri dalam novel Wedding Agreement karya Mia Chuz ditemukan sebanyak 16 temuan dengan persentase $6 \%$. Hubungan manusia dengan diri sendiri dapat dirinci melalui sifat-sifat sebagai berikut. (1) sabar sebanyak 4 temuan, contoh kutipan novelnya: " $A$-aku sudah mencoba untuk bersabar. Tapi... aku tidak sekuat itu, ” Air mata Tari jatuh. Pipinya basah. "Aku benar-benar mencoba memperbaiki pernikahan ini. (Chuz, 2019: 184). Dari kutipan tersebut dapat diketahui bahwa Tari mulai lelah menghadapi sikap Bian. Tari sudah sangat bersabar menerima sikap suaminya. Sabar merupakan tabah, tahan menghadapi cobaan. (2) muhasabah 3 temuan, contoh kutipan novelnya: "Mungkin kita harus sama-sama muhasabah diri," ungkap Tari. (Chuz, 2019: 297). Kutipan tersebut menceritakan saat Bian dan Tari sedang ada masalah. Tari tak ingin terburu-buru mengambil keputusan, ia juga ingin agar Bian merenungkan perbuatannya dan introspeksi diri supaya menjadi pasangan suami istri yang lebih baik dan bahagia. Dalam menjalani kehidupan akan banyak cobaan yang akan dihadapi, oleh karena itu harus selalu bermuhasabah agar dapat menjalani kehidupan yang lebih baik (3) pantang menyerah 3 temuan, contoh 
kutipan novelnya: Tari tidak tahu sampai kapan ia bisa bertahan, tetapi saat ini ia belum menyerah. Insya Allah suaminya akan kembali kepadanya. (Chuz, 2019: 98). Kutipan tersebut menceritakan sifat pantang menyerah Tari. Dapat disimpulkan bahwa manusia tidak boleh putus asa dalam menghadapi kesulitan atau masalah. Dengan bekerja keras dan pantang menyerah pasti akan ada jalan. (4) mandiri sebanyak 4 temuan, contoh kutipan novelnya: Sudah empat tahun Tari memulai usahanya sendiri. Berawal dari iseng untuk sekadar menambah uang saku saat kuliah, sampai akhirnya menjadi besar seperti sekarang. (Chuz, 2019: 31). Kutipan tersebut menggambarkan sosok Tari yang mandiri. Kemandirian dalam menghadapi segala hal dapat mendewasakan seseorang serta menjadikan manusia yang lebih baik. (5) bijak sebanyak 1 temuan, contoh kutipan novelnya: "Kata ustazah, ragu-ragu itu datangnya dari setan," nasihat Ami dengan bijaksana. (Chuz, 2019: 244). Kutipan tersebut menggambarkan sikap bijak Ami yang berusaha meyakinkan Tari untuk kembali kepada suaminya. Bijak dalam memilih segala sesuatu agar baik dan bermanfaat bagi diri dan orang lain. Sedangkan hubungan manusia dengan alam atau lingkungan sekitar ditemukan sebanyak 3 temuan dengan persentase 3\%. Contoh kutipan novelnya: Bude menanam beberapa tanaman bumbu di situ. Ketika butuh bambu dapur, Bude bisa langsung mengambilnya. (Chuz, 2019: 9). Kutipan tersebut menggambarkan Bude yang memanfaatkan alam dengan baik. Segala yang ada di bumi ini Allah ciptakan untuk kemanfaatan manusia.

\section{SIMPULAN}

Berdasarkan ulasan pada hasil dan pembahasan dalam penelitian ini dapat disimpulkan bahwa terdapat 118 proses ekranisasi yang terjadi pada unsur alur, tokoh, dan latar, yaitu adanya penciutan, penambahan, dan perubahan variasi. Penciutan alur, tokoh, dan latar terjadi karena media yang digunakan dalam pembuatan novel dan film berbeda. Penambahan alur, tokoh, dan latar dalam film secara keseluruhan masih relevan dengan cerita yang ada dalam novel, hanya saja pada visualisasi dalam film dibuat lebih menarik, sedangkan untuk perubahan bervariasi alur, tokoh, dan latar yang dilakukan dalam visualisasinya ke bentuk film secara keseluruhan tidak jauh melenceng dari penggambaran yang ada dalam novel. Adapun nilai religius dalam novel Wedding Agreement karya Mia Chuz ditemukan sebanyak 99 temuan nilai religious yang meliputi (a) hubungan manusia dengan Tuhan sebanyak 63 temuan, (b) hubungan manusia dengan manusia sebanyak 17 temuan, (c) hubungan manusia dengan diri sendiri sebanyak 16 temuan dan (d) hubungan manusia dengan alam sebanyak 3 temuan..

\section{DAFTAR PUSTAKA}

Ali, M. D. (2013). Pendidikan Agama Islam. Jakarta: Rajawali Pers

Anto, P., \& Rahman, F. (2018, October). Jasus Bahasa: Suatu metode pembelajaran bahasa asing di pesantren modern (representasi dalam novel berlatar pondok 
modern Gontor). In Pesona: Pekan Seminar Nasional Pendidikan Bahasa dan Sastra Indonesia (Vol. 1, No. 1, pp. 21-33).

Chuz, M. (2018). Wedding Agreement. Naniko Publisher.

Damono, S. D. (2005). Pegangan penelitian sastra bandingan. Jakarta: Pusat Bahasa.

Fathurrohman, M. (2015). Budaya religius dalam peningkatan mutu pendidikan: tinjauan teoritik dan praktik kontekstualisasi pendidikan agama di sekolah. Yogyakarta: Kalimedia.

Ginanjar, N. (2012). Pengkajian prosa fiksi: Teori dan Praktik. Surakarta.

Kasiram, M. (2010). Metodologi penelitian kualitatif-kuantitatif. Malang: UIN Maliki Press

Malinda, R. (2013). Transformasi novel Pintu Terlarang karya Sekar Ayu Asmara ke dalam film. Skripsi. Universtas Pendidikan Indonesia: Fakultas Bahasa dan Seni.

Rahman, F., Anto, P., \& Maskur, A. (2018). Interferensi bahasa Arab terhadap bahasa Indonesia dalam percakapan santri (kajian pada novel Negeri 5 Menara). Imajeri: Jurnal Pendidikan Bahasa dan Sastra Indonesia, 1(1), $12-23$.

Riduwan. (2010). Skala pengukuran variabel-variabel Penelitian. Bandung: Alfabeta.

Rokhmansyah, A. (2014). Studi dan pengkajian sastra: Perkenalan awal terhadap ilmu sastra. Yogyakarta: Graha Ilmu.

Saryono, D. (2015). Meneroka peta sastra Indonesia terkini. Makalah disampaikan dalam Sarasehan Sas-tra dan Budaya, diselenggarakan oleh Fakultas Sastra Universitas Negeri Malang.

Suseno, WS. (2010). Filmisasi karya sastra indonesia: Kajian ekranisasi pada cerpen dan film "Tentang Dia". Diakses pada 4 Juni 2020 https://bensuseno.wordpress.com/2010/02/22/filmisasi-karya-sastraindonesia-kajian-ekranisasi-pada-cerpen-dan-film-\%E2\%80\%9Ctentangdia\%E2\%80\%9D/ 